\title{
Performing Arts and Embodied Designs: An Analysis of Sam Ukala's The Slave Wife
}

\author{
Nasir, Taofiq Olaide \\ Department of Theatre and Media Arts, Federal University, Oye-Ekiti, Ekiti State, Nigeria \\ Bello Olakunle Idris \\ Department of Performing and Film Arts, Elizade University, Ilara-Mokin, Ondo State, Nigeria
}

\begin{abstract}
Contextually, the theatre is an avenue where various artistic personnel of different professional backgrounds converge with their respective works, with the aim of assessing, evaluating and creating a befitting piece. With Fredrick Hegel's statement as spring board, this study explicates the various developmental stages involved in the apparent discovery and identification of an art work in most appropriate manner. Thus, reflecting the transformational order and discovery process involved in the realization of an art piece. It is widely believed that performing arts encompass artistry that is expressed either through dance, drama or musical performances among others. However, the realization of what is particularly artistic has several shapes, forms and perhaps stages. This paper analyses Hegel's philosophical submission on "the rational being rendered sensible" in relation to appearance, form and content. From the stage of conception and performance, we focused on the aesthetics of production in Sam Ukala's The Slave Wife. It then submit that it's of great necessity to re-establish the importance of thoughtful coordination among performance arts vendors on professional grounds as gateway to having a good work of arts at the end of the day.
\end{abstract}

Index Terms - performing arts, culture, artistic personnel, organogram, The Slave Wife

\section{INTRODUCTION}

\section{CONCEPTUALIZATION OF ARTS}

There are divergent definitions of what constitute Art. Plato, Aristotle and Plotinus saw art as an imitation of reality. For Plotinus, art should be beautiful. In their respective works, Abiola Christopher (2013) informs that, Joshua Reynolds opines that art was an enlargement, not an imitation of nature; while Ernst Cassier proposed art to be a symbolic form. (p.47) Barclays Ayakoromah (2016) submits that "Art is an interpretation of reality expressed in a distinctive way" (p.13). From the various assertions on arts, Rudolf (1974) has quickly observed that "Art is the most concrete thing in the world" (p. 37). Throughout the ages, art has played a crucial role in life. Believably, culture certainly comprises more than art, but art has played a dominant role in sustenance and propagation of culture. Art is powerful, because it can convey so much information, through a self-created language. From the foregoing, it is apt to say that art is essential to human survival because it provides guidance and support to the mind which is the mechanism essential to survival. On a more philosophical, deep and critical note, Harold Williams notes that:

It is difficult to imagine a society without the arts. What dark and empty souls would populate an environment without paintings, statues, architecture, drama, music, dances, or poems. The arts define what is meant by civilization. They are part of the foundation and the framework of culture. There is no better time to discuss and foreground the virtues of the arts to civilization than this age. The arts are a major avenue of refining our humanity. (Harold Williams, 1995 in Ackley Anne, 2000, p. 171)

Harold Williams' submission implies that Art could be said to be truly universal as it primarily reaffirms one's values and being. Its practice then implies the selective recreation of reality according to an artist's metaphysical disposition. Thus, for the sole fact that the mind responds to the dictates of its nature, reason and logic, the artist must equally reciprocate by presenting his message in an intelligible format. Naturally, art must be appreciable without the aid of the artist or guide book. This makes art intelligible - an art must speak for itself.

Objectively, any work of art tends to define or redefine life in utmost sincerity. It should be noted that, one of the significant goals of arts is the contribution to knowledge and growth of humanity by extension. A kind of knowledge that virtually cuts across creative understanding to the totality of man's existence. Simply, the world becomes fertile through the embrace and appreciation of art by humans. It should be noted that, art, especially in Africa is not a mere expression of efforts or fulfillment of art for art's sake; rather, when an artist perceives and interprets reality, he does acquire and transmit knowledge simultaneously and this has intrinsic connotation. Art then further modifies one's knowledge of interpretation.

Furthermore, in as much as art requires an artist to have credible sense to absorb; to carve; to transform; and ability to think fast in every situation; he is bound by the notion of experience. To a large extent, experience determines the foresight which an artist can ever attain. As a result, this experience could be in two forms- Environmental factor and 
Psychological imperative.

Environmental factor being a form of artistic experience implies that, the expressive work of an artist is a revelation of the environment that has moulded him. On a peculiar note, all works of art contain subject-matter, which is reflected by the world as the artist has gradually assimilated in the development of self-personality. Thus, "no artist can create on their own, apart from any outside stimuli, a work of art" (Saidu, 2016, p. 54).

On the other hand, unlike the environmental factor which is general in nature, the psychological imperative particularly dwells on the artist's ability to reconcile his experience with self and others (especially at a most personal and reflective level); thereby creating a piece through it. This thought could be well understood along the lines of naturalism as it actually relates to theatre, which maintains that, an artist is expected to pay attention to very accurate and precise details, and portrays things as they are.

\section{Methodology}

This paper employs the qualitative method using content analysis in its reaction to the raised issues in the study. In employing this method, researchers made a radical departure from the interpretation of numerical data but subject the paper to thorough investigation and lucid explanation of the text. The primary source of data is The Slave Wife written by Sam Ukala and published by Ibadan University Press. Also, journals, on-line articles and other scholarly materials are equally used as additional source aimed at having deeper discourse of the issues raised.

\section{RESULTS AND ANALYSIS}

The Theatre: Components and Elements of Activity.

As it has been noted at the prefatory stage of this paper that the theatre is an avenue where various artistic personnel of different professional backgrounds converge to produce a work of art, it becomes clear that art is a work in process or a process within a process. The concerned personnel may include "the actor, director, managers, carpenter, tailor, technician, light designer and audience among others (Olawunmi, 2009, p. iv). In this regard, the collective essence of art is required to be fully deployed. As an integral mechanism for the actualization of an art work, purposeful collaboration should not be in any way compromised. This is because "the art of the theatre in its manifold possibilities can be most absorbing not only in the years of learning the basics but in the arena of performance and production" (Adelugba, 2010, p. 9). This could be observed through critical analysis of the role of the playwright (stage of conceiving) through to the audience (stage of consumption).

Playwriting is said to be a personal, emotional and subjective art. As such, a playwright writes to fill a vacuum. Just as Achebe (1986, p vi) metaphorically refers that "playwriting is like filling the open gap in a book shelf". Relatively, the book shelf is the society; the open gap is the social vice; while the play is a correctional statement. "Playwriting is an investigative immersion into the human psyche and environment to harvest and represent the human condition for critical evaluation directed to edify the human soul" (Binebai, 2013, p. 427).

Often times, the playwright may choose to be essentially original or think upon an existing work, thereby creating an insight from such work. As a raw creative material, "a play is a letter from the playwright to the director, actors and other members of the production informing them of a particular vision of his or hers (Yerima, 2003, p. 15). Here, the playwright becomes an ideologist and (creative) designer - set, lights, properties, make-up, costume and more. This is because, before or during the process of writing, the playwright has consciously buried his creative prowess in the grave of constructive illumination. Here, he creates in his mind, a particular type of stage for his work; his inner sight designs character/characterization; he pictures the scenic requirements. These and some more performance requirements are what the playwright usually stipulates on the opening leaves of his work or at the beginning of each scene/situation/movement. In some cases, especially in African context, the playwright adopts the eclectic artistic nature, by infusing songs and dances in his creative piece. This paper shall therefore make a reference to a particular performance, and attempt a critical review of Sam Ukala's The Slave Wife.

\section{DisCUSSION}

\section{SYNOPSIS OF THE SLAVE WIFE}

The Slave Wife tells the story of a jealous wife, who struggles to maintain her privileged position in a polygamous royal home through overt and covert means. Ogiso, the Oba of Idu, is anxious to sire a male child who will inherit the throne from him. He enlists the support of his chiefs, and most especially that of Obi, the one-eyed oraclist, who after consulting his oracle, tells Oba Ogiso to marry one of his slaves. Apparently, this has not solved the problem, because as Oba Ogiso tells Obu:

The slave you asked me to marry, I have married. The blood of my body has fattened her buttocks not her belly. No heir has been born, and this kingdom will be deceived no more. (Ukala, 1982, p.5)

Thereafter, Obu consults his oracles and instructs Oba Ogiso to feed his ancestors and his wives with "mashed yams", and that the wife who eats the alligator pepper, which the Oba hides in the yam, shall give him a son. Hence, the necessary ritual is performed, and after sometime, the Oba's wives indeed become pregnant, and as it is the tradition, they are sent out of the palace to give birth. The enslave wife, Igbon, suffers all forms of humiliation and deprivation in 
the palace. Her elevation from slavery to the status of a wife of the Oba does not lessen her yoke. The entire palace and the people of Idu see her as a slave and treat her as such. The Oba and his chiefs mock her elevation to the status of a wife, which in reality she is not. Igbon's composure and action are condescending, however, in the end; the enslaved wife gives birth to a son, who Alahin attempts to destroy. And it is not until the miraculous arrival of her son and her subsequent elevation does Igbon exert her position as a royal wife. She warns Alahin, her major prosecutor, with confidence and a sense of authority in the trial scene. After the chiefs have pronounced the judgment of guilt on Alahin to the effect that nothing short of her blood will cleanse the land. In this dramatic situation, the contempt is unmistakable, but in the end, Igbon is indeed, the Oba's wife.

\section{DIRECTORIAL RESPONSIBILITIES: NEXUS WITH PRODUCTION TEAM}

There is pleasure in viewing art; pleasure that should be enjoyed and encouraged. Performance art comes with a special aura for all parties involved in the build-up- the playwright, Director, actors, technical crew members and of course, audience. To a large extent, it is believed that performance of plays bring out the beauty of what the playwright has courteously imagined on paper coupled with the relative creative weight of the handlers of the given play. In essence, it is like bringing life to the play-text. Brunch (1990, p.1) states that the theatre on premium note "needs three elements: actors, play and audience. But for theatre to actualize its potentials, a person needs to impose a point of view that would penetrate all aspects of the production". That is why Musa (2001) contributes that "the art of performance whether; social, cultural, improvisational, scripted, commissioned or religious can only become reality through the creative endeavor of theatre director in his complex and tasking art of play directing"(P.2). At this level of creative interpretation, various factors are put into keen consideration - Artistic, technical and administrative possibilities. As a re-affirmation of theatrical value, its actualization requires the concerted effort of a team to be ably led by an artistic director. "It is the fact, the complexity of his role in the theatre entails that he must be at the apex of theatre productions" (Arinde, 2012, p. 99). Little wonder Dean and Carra (1980,) submit that, Director's work "is to convey to the audience every segment and quality of a play in its fullest dramatic value" (P.17). Shedding more light on this subject-matter, we cannot but acknowledge Emesealu, when he submits that:

directorial art involves the ability to peruse a playwright's script (where there is one) thoroughly, discover the intended message for the audience and be able to communicate such a message to the actors and actresses who, ultimately, constitute the conduct between the text and the audience... involves the harmonization of the efforts of the lighting personnel, the set-designer and executants, the make-up person, and the costume and wardrobe workers, among others (Emesealu, 2010, p. 72).

The reality of interpreting Sam Ukala's The Slave Wife is indeed a great experience. This is because, the director, to a large extent, carefully brings together all the required performance tools- tangible (costumes, set, lights, props etc.) and intangible (sound, dialogue, acting, tempo/mood etc). The theatrical experience indicates that the director maintained professional relationship with the musicologist and choreographer, who are also members of the group. The way at which the orchestra was conducted added much aesthetical credence to the performance of Sam Ukala's The Slave Wife. This was skillfully implemented by the prompt alertness of the orchestra at every point of call. Hence, making sure that the tempo of performance doesn't drop. The modulation of voice and more gave a clearer picture of situations being enacted on stage, with laudable conformity. Basically, the orchestra played an important role not by only spicing up the mood of the audience, but by also contributing to the flow of performance delivery at all levels of production.

Costume, being an occasional robe reserved for a specific purpose at specific occasions. For the theatre, Douglas (1993, p. 9) submits that costume includes "all the accessories he (the performer) carries as part of his character, all the items related to his hair, dressing and everything associated with his face, body, make-up (including mask if they are substitutes for facial make-up". Wilson (1991, p. 357) in Inegbe and Markson (2013, p. 73) states that:

of the various elements in the theatre, the most personal are costumes because they are actually worn by the performers themselves. Closely related to costumes are other elements or accessories worn by performers such as make-up hairstyles, masks and personal items like bracelets, and necklaces. At the same time, costumes have a value of their own, adding colour, shape and symbolism to the overall effect that is created on stage. (Wilson, 1991, p. 357)

Elsewhere, Roberts (2002, rightly puts that "costume functions not only as a disguise but also as an aid to the wearer in assuming the identity of the character he is impersonating" (p.13). To corroborate the several assertions on costume, Utoh-Ezeajugh (2010) postulates that costumes are "the items of clothing, accessories and ornamentation worn by the actor or actress for the purpose defining character and establishing the circumstances of the character's existence, by situating him/her in time and space". (p.130)

Meanwhile, the issue of costume was appropriately attended to in the performance of Sam Ukala's The Slave Wife. Costumes in the performance reflect the visual style of the production as it also helped actors portray their characters on their creative engagement through the play's action. The use of costumes in the performance enabled the audience to identify each character through appearance, thereby possessing visual potentials of information that convey more meaning to the audience. Thus, we cannot discount the fact that costumes in the play added spectacles to the entire creative piece of work. Notably, the rich royal regalia worn by the king presented Ogiso as an Edo king indeed. Also, the use of neck beads and wrist-beads by the queens complimented their social status thereby giving credence to the submission of Ndu-Udeji (2017) that "costumes are designed to highlight the roles played by a character and are used to 
establish mood and to enhance the physical appearance of the character" (p.189). Symbolically, the entire costumes and props used in the play largely project the cultural identity of Benin people. Another element of performance that enhanced rational manifestation is the technical responsibilities. The technical director did well in combining theories such as naturalism, realism and symbolism to somehow crash into eclecticism. This then informs us of the essence of design to a performance. Design in the theatre transcends mere strokes and lines (Nasir 2000, p.28). The designs in the theatre compliment the director's effort to make a dramatic presentation appropriate and pleasing. Scenery and lighting to a performance. Cassady (1997) stressed that "even when the director has definite ideas about how a setting or lights or props should appear, the designers in carrying out the director's wishes, add their own personalities, their way of viewing the world to their work" (p.318). Thus, Nasir (2011) opines that "it is necessary because apart from the designers providing a channel, they equally assist the director to convey the theme and provide information essential to the understanding and overall success of the play" (p.93). Design often necessitates the consideration and functionality of aesthetics, with keen observation for its economic and socio-political dimensions for both design object and the process. These designs are basically scenic and light designs. Scenic design concerns itself with the way a stage is composed, constructed and built for a particular production. To a meaningful extent, scenic design describes the setting of a play through visual language. As a result of this importance, any theatrical session may be unrealistic without a stage (theatre) just as there cannot be a performance without the actor. In the same vein, the actor in a vacuum in environment of same sort, is at least required. This environment includes the stage its set and properties (Akoh and Musa, 2006, p. 125)

On the twin note, lights corroborate the aesthetic dexterity of a production. Through appropriate colour; mode; variety and shape, light performs prominent role in "aiding a lasting, but pleasant theatrical experience" (Oni, 2004, p. $63-4)$. This informs Nwadigwe's (2002) submission that "in addition to enhancing visual and auditory effectiveness, light and sound design give a performance its unique living quality which cannot be obtained from the plastic arts" (p. 12). Hence, the significance of set and light design cannot be relegated in any theatrical exhibition. In the performance of Ukala's The Slave Wife, the relevance of set and light was well utilized. (Bello, Idaevbor; 2013)

\section{CONCLUSION}

Despite the numerous scholarly assertions on arts, one could come to a concise deduction that, art is life and viceversa. Its emergence and sustenance cannot be divorced from man's rational decision to think, imagine, carve, create and appreciate. Art perhaps in its conception emanates from subjective consciousness, it is regarded as a "dreamer's idle fancy" (Bamidele, 2000, p. 27). Atanda (2013) in his view, submits that:

Art is a specific expression like poetry, novel, play, film, music, painting, sculpture and architecture of social consciousness to narrate or present human activity. In other words, art is an application of skill, in creative imagination, to the production of any form of work of art. From the fore-going, art is biocentricism; that is the human being is the focus of every form of genre of art. (Atanda, 2013, p. 453)

Atanda and Bamidele's respective submissions serve fundamental purpose in our ability to understand the rational existence of art, as well as the transformational garment it procures during the process of creation, interpretation and reception. In relation to the performing arts, this paper made close reference to the performance of Sam Ukala's The Slave Wife. Here, a cursory analysis has been made on the procedures and factors that enhanced the successful interpretation of the play-text to performance. It then comes to our worrying observation that if truly the purposeful beauty of rendering a rational art piece sensible relies mostly on collaborative acknowledgement, there should be deserving credit to all personnel involved in such exercise. Thus, this raises our interrogative mind towards the relegation of a playwright in the play-production process. How come do we construct the theatre organogram without creating a space, even if not apparent, for the playwright; we then place the artistic director at the superlative top?. As such, this paper strongly disagrees with Peter Brook, who refers director as "God". Brook (1968) submits that:

He does not ask to be God and yet his role implies it. He wants to be fallible, and yet an instinctive conspiracy of the actors is to make him the arbiter, because an arbiter is so desperately wanted all the time. In a sense, the director is always an impostor, a guide at night who does not know the territory and yet he has no choice - he must guide, learning the route as he goes (Brook, 1968, p. 38)

By this, the implication of Brook's submission super-imposes the director on every other personnel involved in a play production, even the playwright. But it remains obvious that, for a director to work, he needs a material; such material is the play. How then do we revere the creator of such play? In submission, the concern at this point is that, in rendering an ideology*y; a creative thought sensible, one should do a sincere and critical identification of all elements and contributors, who in their respective disciplines, commit their expertise for such artistic reality.

\section{REFERENCES}

[1] Achebe, C. (1986). African Writers: Experience and Ideology. NJ: Campbell Publications.

[2] Ackley, K.A. (2000). Perspectives on Contemporary Issues: Readings across the Discipline. (Ed.) Fort Worth. TX: Harcourt College. 
[3] Adegbite, A. (2012). Stage lighting deployment in Ogun Lakaaye: A post-production assessment. In: The dramaturgy of a theatre sociologist. A festschrift in honour of Ayo Akinwale. (Ed.) Adeoye, A.A. pp. 344 - 356. Ilorin: Department of Performing Arts, University of Ilorin.

[4] Adelugba, D. (2010). Foreword. In: The theatre of Ola Rotimi production and performance dynamics. (Ed.) Emmanuel Emasealu. pp. 8 - 9. Minna: Gurara Publishing.

[5] Akoh, D.A. and Musa, D.E. (2006). Scenography, the stage and African plays: Experiments and challenges of the University of Jos open theatre model. In: Technical theatre practice in Nigeria trends and issues. (Eds.) Duro Oni and EnessiOdodo. pp. 125 - 138. Lagos: CBAAC.

[6] Arnheim, R. (1974). Art and visual perception.Berkeley: University of California Press.

[7] Arinde, T.S. (2012). Directorial style and skill of Ayo Akinwale in the Mountains of wealth. In: The dramaturgy of a theatre sociologist: Festschrift in honour of Ayo Akinwale. (Ed.) Adeoye, A.A. pp. 98 - 107. Ilorin: Department of Performing Arts, University of Ilorin.

[8] Atanda, Yemi. (2013). Periscoping. The Beatification of Area Boy through L.O. Bamidele's lenses on sociology of literature. In: Arts, culture and communication in a postcolony: A festschrift for Lawrence OlanreleBamidele. (Eds.) Ameh, D.O. and Stephen, E.I. pp. 429 - 463. United Kingdom: Alpha Crownes Publisher.

[9] Baclays Ayakoroma (2016) "Dance on his Grave" in Ododo \& Omoera (ed) Theatre, Media and Cultural Re-engineering in Nigeria. Ibadan. Kraft books.

[10] Bamidele, L.O. (2000). Literature and sociology. Ibadan: Stirling-Horden Publishers (Nig.) Ltd.

[11] Binebai, B. (2013). Identity politics in Niger Delta drama: Nationalism of separatism in Ambakederemo'sIsaac Boro. In: Arts, culture and communication in a postcolony: A festschrift for Lawrence OlanreleBamidele. (Eds.) Ameh, D.O. and Stephen, E.I. pp. 427 - 428. United Kingdom: Alpha Crownes Publisher.

[12] Brook, P. (1968). Empty space. New York: Macmillan Publishing Company.

[13] Brunch, D. (1990). Directing theatre: A guide to studying the relationship between engineering and theatre. Retrieved from http://dbrunch.hypemart.net on $25^{\text {th }}$ June, 2018.

[14] Culture and Its Manifestations: Know Nigeria (1991).Series 3. Lagos: Federal Ministry of Information.

[15] Cassady M. (1975). The Theatre: An Introduction. Chicago. NTC Publishing Group.

[16] Christopher Abiola. (2013) The Artist and Corruption Syndrome in Nigeria. In Samson Ogunniyan's (ed) Art and its Functionality. Lagos. Roots, Books and Journals publishers.

[17] Dean, A. and Lawrence, C. (1980).Fundamentals of play directing. New York: Holt, Rinehart and Winston.

[18] Douglas, R. (1993). Stage costume design: Theory, technique and style. New Jersey: Prentice-Hall.

[19] Emesealu, E. (2010). The theatre of Ola Rotimi: Production and performance dynamics.Minna: Gurara Publishing.

[20] Fabiyi, O.A. (2011). Theatre: Mirrors and reflections.Somolu: Hope Media.

[21] Harold, W. (1995). Don’t ignore the Arst. USA Today Magazine.

[22] Idaevbor, B. (2013). Journal of Pan African Studies. Vol 6 Nbr. 5. October-October 2013.

[23] Musa, R. (2001). Directing style and the Nigerian theatre. Being a paper presented at SONTA 2001 held at the Department of English and Drama, Ahmadu Bello University, Zaria between $28^{\text {th }}$ November and $2^{\text {nd }}$ December.

[24] Nasir, T.O (2000). "Design as a Vehicle of Play Interpretation2 An unpublished M.A thesis submitted to the Department of Theatre Arts, University of Ibadan.

[25] Nasir, T.O (2011). "Art and Design: Issues and Discourse" in Duro Oni \& Sunday Ododo (ed) Technical Theatre and The Performing Arts in Nigeria. Lagos. CBAAC..

[26] Ndu-Udeji, M. (2017). "How to Costume a Film" in Ekwuazi H (ed) Media: A Production Resource Book. Nasarawa. Whiteline Publishers.

[27] Olawunmi, A.O. (2009). Professional modern repertory in Nigeria.Ogun: Lisabi Press.

[28] Omoera, O.S. (2013). Rejuvenating African Indigenous Performing Arts: A study of Ekaba. In: Arts, culture and communication in a postcolony: A festschrift for Lawrence Olanrele Bamidele. (Eds.) Ameh, D.O. and Stephen, E.I. pp. 34 47. United Kingdom: Alpha Crownes Publisher.

[29] Oni, D. (2004). Stage Lighting: The Nigerian Perspective. Lagos: SONTA.

[30] Reilly, H.J. and Phillips, M.S. (1998). Introducing Theatre. New York: Forbes Custom Publishing.

[31] Roberts, V. (1974).On stage - A History of the Theatre. New York: Harper and Row.

[32] Saidu, E.R. (2016). Creating arts: Creator's insights. Lagos: Readers' Prints.

[33] Ukala, S. (1982).The Slave Wife. Ibadan: University Press.

[34] Utoh-Ezeajugh, T. (2017). "Promoting Minority Culture through Costume and Make-up. Sam Ukala's Break a Boil in production". In: Theatre and Mminority Rights: Perspectives on the Niger Delta. (Ed.) Austin, O.A. pp. 129 - 141. Ibadan: Kraft Books Ltd.

[35] Wilson, E. (1991). The Theatre Experience. New York: McGraw Hills.

[36] Yerima, A. (2003). Basic techniques in playwriting. Ibadan: Kraft.

Taofiq Olaide Nasir was born in Ibadan, Oyo State, Nigeria on the $27^{\text {th }}$ of September. He is a product of the prestigious University of Ibadan where he earned his M.A in Theatre Arts and Ph.D in theatre Arts after his B.A degree in Dramatic Arts from Obafemi Awolowo University, Ile-Ife.

A versatile writer, dramaturg, theatre technologists who effectively combines theory with praxis, he studied under the tutelage of renowned theatre artist which includes Professor Femi Osofisan, Professor Bode Sowande, late Professor Ola Rotimi and late Professor Dapo Adelugba. He started lecturing at Federal College of Education (SP) Oyo, before moving to Olabisi Onabanjo University, Ogun State. He currently lectures at Federal University, Oye-Ekiti, Ekiti State. 
Dr. Nasir is the first African to have a doctoral degree using Drama as Therapy. He is a member of Society of Nigeria Theatre Artists (SONTA), National Association of Nigerian Theatre Arts Practitioners (NANTAP), and currently the P.R.O of Association of Nigerian Authors (ANA), Ekiti State Chapter. His areas of interest are Applied Drama, Theatre Technology, Criticism and Directing. He has to his credit not less than fifteen years of practical engagement with inmates of prison and patients of General Hospitals and Neuro-psychiatric Hospitals.

Bello Olakunle Idris was born in Bariga area of Lagos on the 14th of February, 1988. He attended the prestigious CMS Grammar School, Lagos for his secondary education. He obtained Bachelor of Arts degree in Performing Arts from Olabisi Onabanjo University, Ogun State. He then proceeded to University of Ilorin for his master's degree, where he scored PhD grade. He is currently a $\mathrm{PhD}$ candidate in the Department of Theatre and Media Arts, Federal University, Oye-Ekiti, Nigeria. His research interests are Applied theatre/criticism and Theatre For Development.

He currently lectures at the Department of Performing and Film Arts, Elizade University, Ondo State, Nigeria. 